\title{
Assessment of Land-Use/Cover Changes and Its Ecological Effect in Rapidly Urbanized Areas-Taking Pearl River Delta Urban Agglomeration as a Case
}

\author{
Panpan $\mathrm{Hu}^{1,2}{ }^{1, \text { Feng } \mathrm{Li}^{3}}{ }^{3}$, Xiao Sun ${ }^{4}$, Yali Liu ${ }^{1,2}$, Xinchuang Chen ${ }^{1,2} \mathbb{D}$ and Dan Hu ${ }^{1,2, *}$ \\ 1 State Key Laboratory of Urban and Regional Ecology, Research Center for Eco-Environmental Sciences, \\ Chinese Academy of Sciences, Beijing 100085, China; pphu_st@rcees.ac.cn (P.H.); liuyali@ucas.ac.cn (Y.L.); \\ xcchen_st@rcees.ac.cn (X.C.) \\ 2 University of Chinese Academy of Sciences, Beijing 100049, China \\ 3 School of Architecture, Tsinghua University, Beijing 100084, China; feng_li@tsinghua.edu.cn \\ 4 Institute of Agricultural Resources and Regional Planning, Chinese Academy of Agricultural Sciences, \\ Beijing 100081, China; sunxiao@caas.cn \\ * Correspondence: hudan@rcees.ac.cn; Tel.: +86-010-628-49-199
}

Citation: Hu, P.; Li, F.; Sun, X.; Liu, Y.; Chen, X.; Hu, D. Assessment of Land-Use/Cover Changes and Its Ecological Effect in Rapidly Urbanized Areas-Taking Pearl River Delta Urban Agglomeration as a Case. Sustainability 2021, 13, 5075. https:// doi.org/10.3390/su13095075

Academic Editor: Young-joo Ahn

Received: 31 March 2021

Accepted: 28 April 2021

Published: 30 April 2021

Publisher's Note: MDPI stays neutral with regard to jurisdictional claims in published maps and institutional affiliations.

Copyright: (c) 2021 by the authors. Licensee MDPI, Basel, Switzerland. This article is an open access article distributed under the terms and conditions of the Creative Commons Attribution (CC BY) license (https:/ / creativecommons.org/licenses/by/ $4.0 /)$.

\begin{abstract}
Based on the land-use data of 2000 and 2015, this study makes a quantitative analysis of the ecological environment effect in Pearl River Delta using the ecological environment quality index and the ecological contribution rate of land-use change types. The results showed the following: (1) During 2000-2015, the land-use changes in Pearl River Delta mainly manifested in the reduction of cultivated land, forest land, water area, and unused land, while the area of construction land and grassland showed an increasing trend. The quality of ecological environment in the Pearl River Delta was largely stable but slightly declined overall; (2) Over the past 15 years, the comprehensive ecological environment index of the Pearl River Delta urban agglomeration has decreased by 0.02 . With an average annual decrease of $0.11 \%$. The spatial expansion caused by urbanization had the most profound impact on the decline of the ecological environment quality in the Pearl River Delta; (3) The eco-environmental quality indices of various cities in the Pearl River Delta declined to varying degrees. The city with the largest decline was Dongguan, followed by Shenzhen and Zhongshan. The spatial differentiation characteristics of the eco-environmental quality index indicate that the ecological quality preferences of cities distributed around the study area and close to the inland areas, while the ecological quality of the central coastal cities are biased. The quality of the ecological environment is related to the basis of the regional ecological environment. The research results have important practical significance for maintaining regional ecological balance and promoting the sustainable use of land resources, and they provide a reference for the study of the ecological and environmental effects of land-use changes in key cities in economically developed areas.
\end{abstract}

Keywords: land-use/cover change; eco-environmental quality; Pearl River Delta urban agglomeration

\section{Introduction}

The ecological environment is the basic guarantee for human survival and the material basis for social development [1]. With the development of society, the relationship between human activities and the ecological environment has become increasingly close, which has caused great damage to the global ecosystem, and the ecological environment problems have become more and more serious [2,3]. In particular, the rapid development of urbanization in recent years has accelerated the damage caused to the surface environment by human activities, resulting in increasingly prominent urban ecological and environmental problems, which seriously threaten the urban ecological security [4,5]. Due to the changes in the ecological environment caused by the continuous advancement of the urbanization process, what methods should be used to dynamically monitor the ecological environment quality of the urban agglomeration area in a comprehensive, multiscale, and long-term 
sequence? Therefore, scientific monitoring and evaluation of the impact of human activities on the urban ecological environment and its temporal and spatial changes and optimizing the spatial pattern of the country based on its key driving factors $[6,7]$ have become an important means and hot research content for protecting the ecological environment. It has important theoretical and practical significance for coordinating the relationship between human activities and the ecological environment, promoting the harmony between man and nature, and promoting the sustainable development of social economy [8,9].

Recently, research progress on the ecological environment effects of land-use change has the following characteristics: The research scope has gradually expanded from ecologically fragile areas or economically backward areas to economically developed areas $[10,11]$, for example, from the farming pastoral ecotone in northern China to the research on Jiangsu Province $[12,13]$. The research focus has gradually expanded from single-factor water body, forest, carbon, etc., to the regional overall ecological environment effect [14-19]. The research scale has gradually expanded from single city to urban agglomeration area, for example, from Wuhan city to the core area of Yangtze River Delta [20,21]. In the above study, the land-use types caused by urban expansion have undergone great changes in urban agglomerations [22], which has significantly affected ecological and environmental effects $[23,24]$. Therefore, it is essential to study the eco-environmental effects of urban agglomerations [25-27].

As one of the three major urban agglomerations in China, in recent years, with the implementation of regional planning, the new layout of large-scale industries, the construction of innovative demonstration zones, etc., the land-use pattern of the Pearl River Delta region has also undergone significant changes. Secondly, with the rapid development of regional economy, large-scale aggregation of population, and the continuous expansion of urban and construction land, land resources are relatively poor, and the contradiction between humans and land is prominent. It is particularly important to take into account the coordinated development of land development and ecological construction [28]. Thirdly, as an important part of the construction of Guangdong, Hong Kong, and Macao Bay area, the special ecological location of the Pearl River Delta plays a key role in the ecological security of the whole Guangdong, Hong Kong, and Macao Bay area. Therefore, to master the ecological quality of the Pearl River Delta urban agglomeration is helpful to improve the level of regional sustainable development and lay a scientific foundation for regional ecological environment protection [29].

Therefore, taking the urban agglomeration of the Pearl River Delta as the object of research, and with the support of GIS, the ecological environment effects of land-use change were comprehensively evaluated based on the quantitative valuation method to describe the development of the Pearl River Delta. Furthermore, this study identifies some of the problems existing in the process of land development and ecological construction in the Pearl River Delta region, so as to provide scientific basis for land planning and ecological environmental protection in the region. Moreover, the study on the ecological environment effects of land-use change under the background of rapid urbanization is of great practical importance in maintaining the regional ecological balance and promoting the sustainable use of land resources. At the same time, it also provides a reference for the study on the ecological environment effects of land-use change in key cities in economically developed areas.

\section{Materials and Methods}

\subsection{Study Area}

The urban agglomeration in the Pearl River Delta is situated in the southeast of Guangdong province, in the lower reaches of the Pearl River, adjacent to Hong Kong and Macao (Figure 1). Guangzhou and Shenzhen are the core cities of the region, with other major cities including Zhuhai, Foshan, Huizhou, Dongguan, Zhongshan, Jiangmen, and Zhaoqing. The Pearl River Delta is known as the "South Gate of China" because of its geographic advantage of being positioned across the sea from Southeast Asia. The 
area is below $255 \mathrm{~m}$ above sea level, and it has a central plain and is surrounded by hills, mountains, and islands. The region has a subtropical climate in which the rainy season is synchronized with the hot season. The annual average temperature is $21-23 \mathrm{mpe}$, and the average annual precipitation is over $1500 \mathrm{~mm}$. The typical vegetation is subtropical evergreen broad-leaved forest. The region is characterized by a multichannel water network and various different wetland types. The estuary delta extends to the South China Sea.

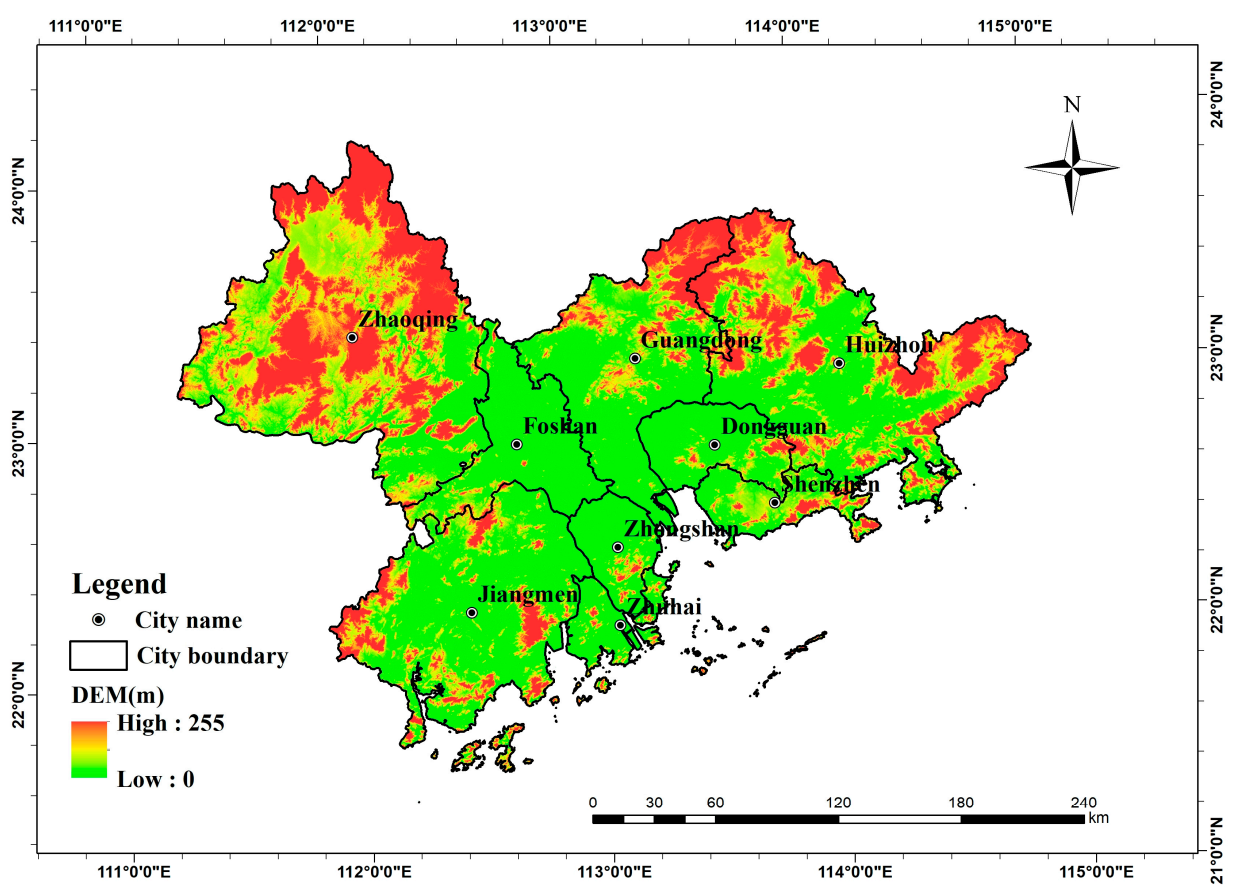

Figure 1. Location and administrative divisions of the Pearl River Delta.

\subsection{Data Sources}

This study is based on the land-use data produced by the Institute of Geographic Sciences and Natural Resources Research, Chinese Academy of Sciences. The obtained data were based on the interpretation of Landsat image data. After field verification, the classification accuracy is $87.94 \%$, which meets the mapping requirements [30]. Land-use classification includes the first-level classification system (6 categories) and the second-level classification system ( 25 categories). The land-use types in the study area were merged and analyzed. The six types in the first-level classification (cultivated land, woodland, grassland, water area, construction land, and unused land in the first-level classification) were analyzed. Figure 2 presents the land-use classification map of the Pearl River Delta urban agglomeration based on the first-level classification system. 

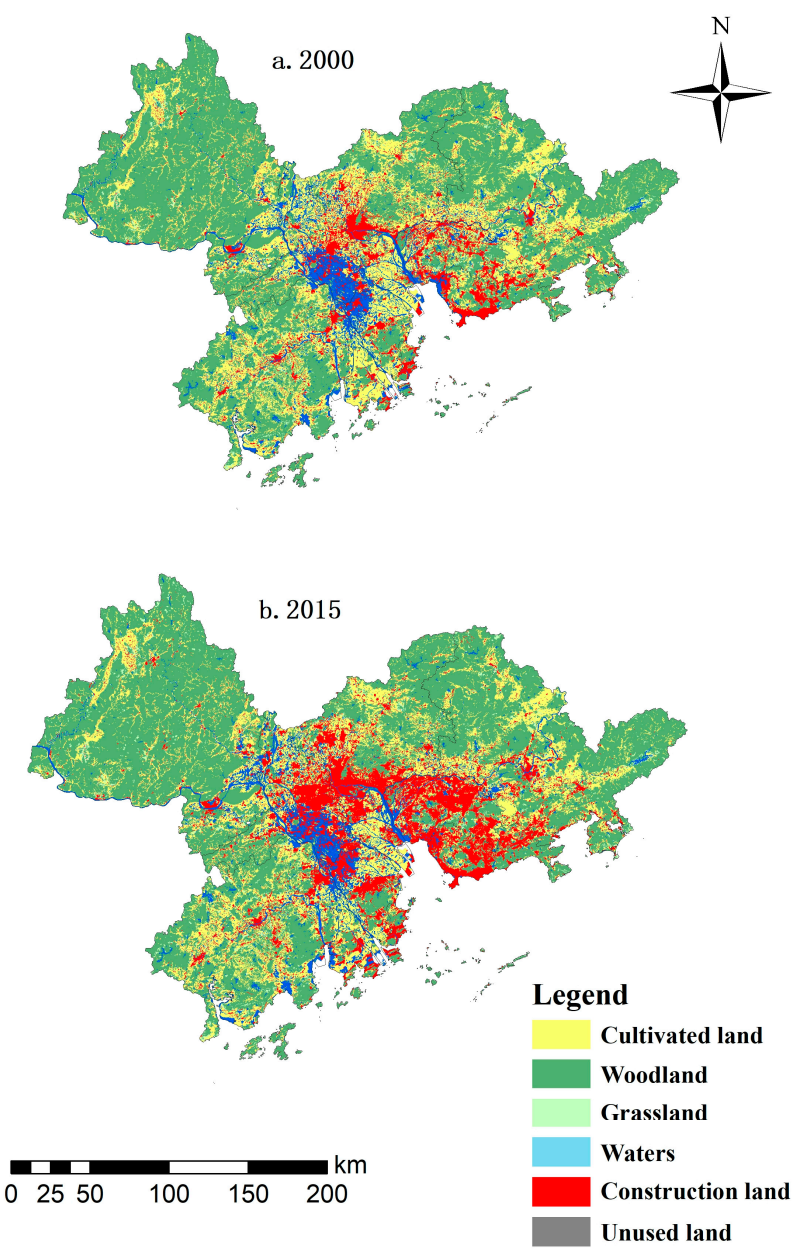

Figure 2. Land-use pattern of different years in Pearl River Delta (2000-2015).

\subsection{Research Methods}

\subsubsection{Analysis of the Land-Use Transfer Types}

With the support of GIS, through spatial superposition of remote sensing images and land-use maps in different periods, the transfer matrix of land-use types was obtained, and then the process of land-use change was analyzed. In practical application, according to the principle of map algebra [31], for any two periods ( $k$ and $k+1)$, a land-use type map $\left(A_{i \times j}^{k}\right.$ and $\left.A_{i \times j}^{k+1}\right)$ can be produced. The calculation formula for the land-use transfer matrix is then as follows:

$$
C_{i \times j}=10 A_{i \times j}^{k}+A_{i \times j}^{k+1}
$$

where $C_{i \times j}$ is a land-use change map from $k$ to $k+1 ; A_{i \times j}^{k}$ is the land-use type map of period $\mathrm{k} ; A_{i \times j}^{k+1}$ is a map of land-use types in the period $k+1$; and $i$ and $j$ represent the different types of land use. When the values of $i$ and $j$ are in the range of 1-10, this formula can be used to calculate land-use transfer.

\subsubsection{Ecological Quality Indicators of Land-Use Types}

In this study, combined with expert scoring and analytic hierarchy process (AHP) and referring to the relevant domestic research, the ecological environment quality of landuse types under the second-level classification system was evaluated by using the fuzzy method. The results are shown in Table 1. Because the second-level classification system of land use has a high resolution and reflects clear ecological differences, the ecological environment quality of land-use types under the second-level classification system can be evaluated and combined with the types and processes of land-use change. By establishing 
the correlation between land-use/land cover and regional ecological environment quality, it is possible to quantitatively analyze the temporal and spatial variation characteristics of regional ecological environment quality by tracking changes in land-use types, quantities, and spatial characteristics.

Table 1. Land-use classification and eco-environmental indicators.

\begin{tabular}{|c|c|c|c|c|}
\hline \multicolumn{2}{|c|}{ Level 1 Land-Use Types } & \multicolumn{2}{|c|}{ Level 2 Land-Use Types } & \multirow{2}{*}{$\begin{array}{c}\text { Ecological } \\
\text { Quality Index }\end{array}$} \\
\hline Number & Name & Number & Name & \\
\hline \multirow[t]{2}{*}{1} & Cultivated land & 11 & Paddy field & 0.30 \\
\hline & & 12 & Dry land & 0.25 \\
\hline \multirow[t]{4}{*}{2} & Forest & 21 & Forest & 0.95 \\
\hline & & 22 & Shrub land & 0.65 \\
\hline & & 23 & Sparse woodland & 0.45 \\
\hline & & 24 & Other forest & 0.40 \\
\hline \multirow[t]{3}{*}{3} & Grassland & 31 & $\begin{array}{l}\text { High-coverage } \\
\text { grassland }\end{array}$ & 0.75 \\
\hline & & 32 & $\begin{array}{l}\text { Medium-coverage } \\
\text { grassland }\end{array}$ & 0.45 \\
\hline & & 33 & Low-coverage grassland & 0.20 \\
\hline \multirow[t]{5}{*}{4} & Water & 41 & River & 0.55 \\
\hline & & 42 & Lake & 0.75 \\
\hline & & 43 & Reservoir pond & 0.55 \\
\hline & & 45 & Shoal & 0.45 \\
\hline & & 46 & Beach & 0.55 \\
\hline \multirow[t]{3}{*}{5} & Construction land & 51 & Urban land & 0.20 \\
\hline & & 52 & Rural settlements & 0.20 \\
\hline & & 53 & Other construction Land & 0.15 \\
\hline \multirow[t]{4}{*}{6} & Unused land & 61 & Sandy land & 0.01 \\
\hline & & 64 & Swamp land & 0.65 \\
\hline & & 65 & Naked land & 0.05 \\
\hline & & 66 & Bare rock gravel land & 0.01 \\
\hline
\end{tabular}

\subsubsection{Regional Eco-Environmental Quality Index}

The overall situation of the ecological environment quality is quantitatively characterized through considering the ecological quality and area proportion of each land use in the region. It can be estimated as follows [32,33]:

$$
E V_{t}=\sum_{i=1}^{N} L U_{i} \times C_{i} / T A
$$

where $E V_{t}$ is the regional ecological environment quality index; $L U_{i}$ and $C_{i}$ are the area and eco-environmental indices of the $i$ land-use types in the region during the $t$ period, respectively; TA is the total area of the region; and $\mathrm{N}$ is the number of land-use types in the region.

\subsubsection{Ecological Contribution Rate of Regional Land-Use Change Types}

The ecological contribution rate refers to the change of regional ecological quality caused by the change of a land-use type and can be expressed as follows [20]:

$$
L E I=\left(L E_{t+1}-L E_{t}\right) L A / T A
$$

where $L E I$ is the ecological contribution rate of land-use change type; $L E_{t+1}$ and $L E_{t}$ reflect the ecological quality index of the initial and final stages of land-use change, respectively; $L A$ is the change area of this type; and $T A$ is the total area of the region. 


\section{Results}

\subsection{Analysis of Land-Use Change in the Pearl River Delta Urban Agglomeration}

3.1.1. Analysis of Land-Use Area and Proportion

Table 2 showed that in 2000, the order of land-use types in the Pearl River Delta was ranked according to the size of the area, which is consistent with the findings of 2015 (forest $>$ cultivated land $>$ construction land $>$ water area $>$ grassland $>$ unused land). However, there was a clear expansion of construction land over the study period with an associated loss of cultivated land and forest.

Table 2. Land-use changes in Pearl River Delta from 2000 to 2015.

\begin{tabular}{|c|c|c|c|c|c|c|c|}
\hline \multirow[b]{2}{*}{ Land-Use Types } & \multicolumn{2}{|c|}{ In 2000} & \multicolumn{2}{|c|}{ In 2015} & \multirow{2}{*}{ Variation $/ \mathbf{k m}^{2}$} & \multirow{2}{*}{$\begin{array}{c}\text { Annual } \\
\text { Reduction } / \mathrm{km}^{2}\end{array}$} & \multirow{2}{*}{$\begin{array}{c}\text { Percentage } \\
\text { Equivalent } \\
\text { to } 2015 / \%\end{array}$} \\
\hline & Area $/ \mathbf{k m}^{2}$ & Proportion/\% & Area $/ \mathrm{km}^{2}$ & Proportion/\% & & & \\
\hline Cultivated land & $14,343.75$ & 26.66 & 12403.88 & 23.05 & -1939.88 & -129.33 & -15.64 \\
\hline Forest & $30,030.21$ & 55.81 & 29184.10 & 54.24 & -846.11 & -56.41 & -2.90 \\
\hline Grassland & 1070.44 & 1.99 & 1103.70 & 2.05 & 33.26 & 2.22 & 3.01 \\
\hline Water & 4139.40 & 7.69 & 3852.22 & 7.16 & -287.18 & -19.15 & -7.45 \\
\hline $\begin{array}{c}\text { Construction } \\
\text { land }\end{array}$ & 4202.02 & 7.81 & 7246.03 & 13.47 & 3044.02 & 202.93 & 42.01 \\
\hline Unused land & 17.34 & 0.03 & 13.13 & 0.02 & -4.22 & -0.28 & -32.14 \\
\hline
\end{tabular}

In the past 15 years, the land-use types in Pearl River Delta mainly depended on forest, cultivated land, construction land, and water areas, of which forest and cultivated land accounted for more than $25 \%$. In particular, the area of forest was higher than $50 \%$, indicating high forest cover in the Pearl River Delta. The proportion of unused land was less than $0.1 \%$, the proportion of grassland was about $2 \%$, and the area of construction land and water area was equivalent, accounting for about $7 \%$.

\subsubsection{Analysis of Land-Use Transfer Matrix}

Using the spatial analysis function of GIS, the land-use data in 2000 and 2015 were analyzed by spatial overlay, and the land-use type change range (Table 3), spatial distribution map (Figure 3), and land-use type transfer matrix of the Pearl River Delta (Table 4) in 2000-2015 were obtained based on Formula (1).

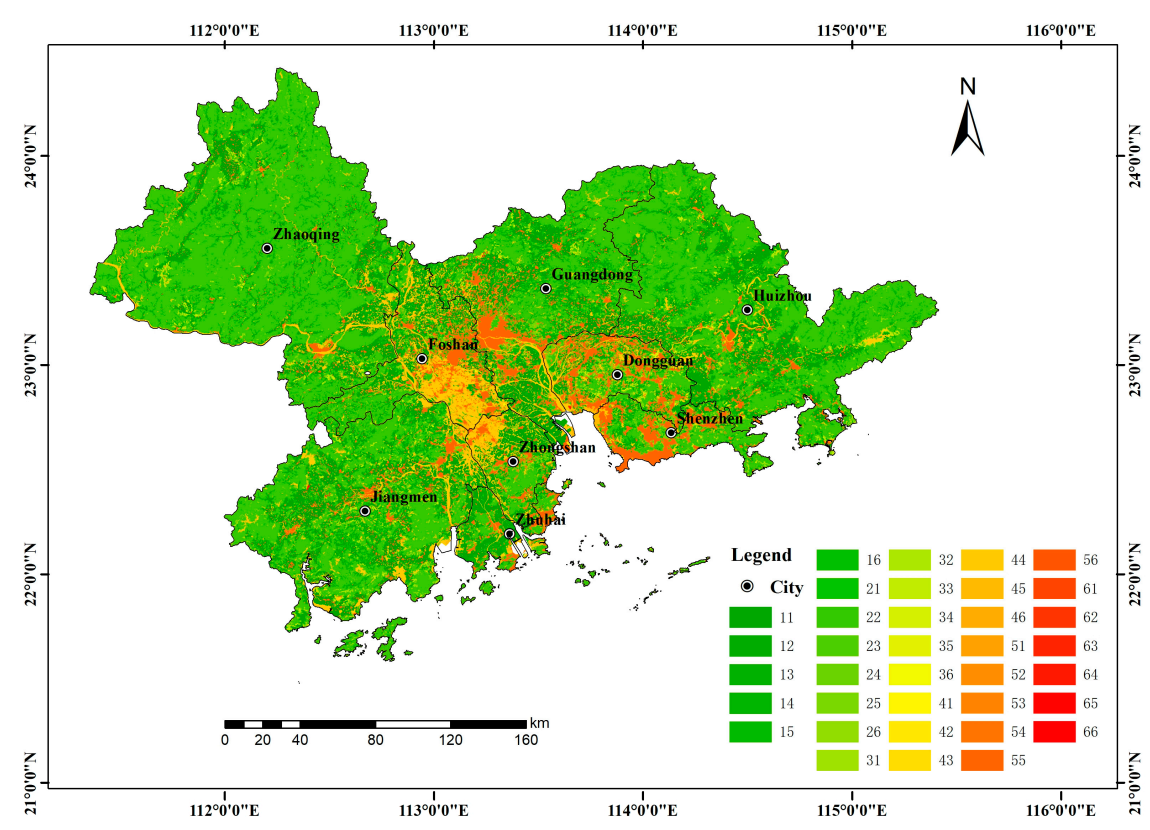

Figure 3. Change of land-use/land cover in Pearl River Delta in 2000-2015. (Note: Numbers denote land type coding, for example, number 12 denotes conversion of cultivated land to forest.) 
Table 3. Transition matrix of land-use type in Pearl River Delta from 2000 to 2015.

\begin{tabular}{cccccccc}
\hline $\begin{array}{c}\text { Land-Use } \\
\text { Types }\end{array}$ & $\begin{array}{c}\text { Cultivated } \\
\text { Land }\end{array}$ & Forest & Grassland & $\begin{array}{c}\text { Water } \\
\text { Areas }\end{array}$ & $\begin{array}{c}\text { Construction } \\
\text { Land }\end{array}$ & $\begin{array}{c}\text { Unused } \\
\text { Land }\end{array}$ & $\begin{array}{c}\text { Total } \\
\text { In 2000 }\end{array}$ \\
\hline $\begin{array}{c}\text { Cultivated } \\
\text { land }\end{array}$ & $12,369.47$ & 86.29 & 1.94 & 213.15 & 1672.71 & 0.07 & $14,343.63$ \\
$\begin{array}{c}\text { Forest } \\
\text { Grassland }\end{array}$ & 14.27 & $29,023.53$ & 147.55 & 26.12 & 817.82 & 0.26 & $30,029.54$ \\
$\quad \begin{array}{l}\text { Water } \\
\text { areas }\end{array}$ & 14.65 & 54.76 & 949.13 & 1.45 & 64.60 & 0.01 & 1070.41 \\
$\begin{array}{c}\text { Construction } \\
\text { land } \\
\begin{array}{c}\text { Unused } \\
\text { land }\end{array}\end{array}$ & 4.75 & 11.15 & 0.22 & 7.70 & 4178.12 & 0.01 & 4201.95 \\
$\quad \begin{array}{c}\text { Total } \\
\text { In 2015 }\end{array}$ & $12,403.83$ & $29,183.56$ & 1103.69 & 3852.09 & 7245.84 & 13.12 & $53,802.12$ \\
\hline
\end{tabular}

Table 4. Transition matrix of land-use type in the Pearl River Delta from 2000 to 2015.

\begin{tabular}{cccccccc}
\hline \multicolumn{2}{c}{ Land-Use Types } & $\begin{array}{c}\text { Cultivated } \\
\text { Land }\end{array}$ & Forest & Grassland & Water & $\begin{array}{c}\text { Construction } \\
\text { Land }\end{array}$ & $\begin{array}{c}\text { Unused } \\
\text { Land }\end{array}$ \\
\hline $\begin{array}{c}\text { Cultivated } \\
\text { land }\end{array}$ & $\mathrm{A}$ & 86.24 & 0.60 & 0.01 & 1.49 & 11.66 & 0.00 \\
\hline Forest & $\mathrm{B}$ & 99.72 & 0.12 & 0.00 & 0.12 & 0.04 & 0.00 \\
\hline \multirow{2}{*}{ Grassland } & $\mathrm{A}$ & 0.05 & 96.65 & 0.49 & 0.09 & 2.72 & 0.00 \\
\hline Water & $\mathrm{B}$ & 0.30 & 99.45 & 0.19 & 0.03 & 0.04 & 0.00 \\
\hline areas & $\mathrm{A}$ & 0.04 & 5.12 & 88.67 & 0.14 & 6.03 & 0.00 \\
\hline Construction & $\mathrm{B}$ & 0.18 & 13.37 & 86.00 & 0.44 & 0.02 & 0.00 \\
$\quad$ land & $\mathrm{B}$ & 0.35 & 0.18 & 0.12 & 87.02 & 12.32 & 0.01 \\
\hline Unused & $\mathrm{B}$ & 5.53 & 0.68 & 0.04 & 93.50 & 0.20 & 0.05 \\
\hline land & $\mathrm{A}$ & 0.11 & 0.27 & 0.01 & 0.18 & 99.43 & 0.00 \\
\hline Note Lind A & 23.09 & 11.29 & 0.89 & 7.04 & 57.66 & 0.04 \\
\hline
\end{tabular}

Note: Line A indicates the proportion of land-use types changed from type $\mathrm{i}$ in 2000 to type $\mathrm{j}$ in 2015 . Line B represents the proportion of land-use type $\mathrm{j}$ in 2015 that changed from type i in 2000.

The area of cultivated land decreased significantly, from $14,343.63 \mathrm{~km}^{2}$ in 2000 to $12,403.83 \mathrm{~km}^{2}$ in 2015 (Table 3). The cumulative reduction area was $1939.8 \mathrm{~km}^{2}$, which accounted for approximately $15.64 \%$ of the cultivated land in 2015 .The main destinations for the transfer of cultivated land were construction land, water areas, and forest, for which the percentages of transfer were $11.66 \%, 1.49 \%$, and $0.6 \%$ (Table 4), respectively. There was a clear urban expansion trend through the occupation of cultivated land in the suburban plain. A total of $213.15 \mathrm{~km}^{2}$ of cultivated land was transferred to water areas because the phenomenon of reclaiming land from lakes changed to returning farmland to lakes. This shows that the policy of returning farmland to lakes in Guangdong province has achieved remarkable results.

The area of forest decreased considerably, with a total reduction of $846.11 \mathrm{~km}^{2}$ (Table 3), which accounted for $2.9 \%$ of the forest land in the Pearl River Delta region. The main destinations for forest transfer were construction land and grassland, with transfer percentages of $2.72 \%$ and $0.49 \%$ (Table 4 ), respectively. Of the forests, $147.55 \mathrm{~km}^{2}$ was degraded into grassland, indicating that there has been clear forest ecosystem damage in the Pearl River Delta region, which should be addressed.

The grassland area increased by $33.26 \mathrm{~km}^{2}$ over the study period, accounting for $3.01 \%$ of the grassland ratio in 2015. The increase of grassland was mainly dependent on the conversion of construction land and forest land. The construction land transferred by $6.03 \%$, and the forest transferred by $5.12 \%$. The transfer of construction land to grassland is the embodiment of urban greening. 
The area under water bodies decreased over the study period. The water area reduced by $287.18 \mathrm{~km}^{2}$, which was $7.45 \%$ of the total water area in 2015 . The main direction of water transfer is construction land, and the percentage of transfer was $12.32 \%$.

Construction land showed the largest increase of all land uses over the study period. The construction land area of the Pearl River Delta has increased by $3044.02 \mathrm{~km}^{2}$. The increase accounted for $42.1 \%$ of the total construction land in 2015 . The increase of construction land was mainly related to cultivated land, forest, and water areas with percentages of transfer of $23.09 \%, 11.29 \%$, and $7.04 \%$, respectively. Construction land expansion was concentrated in Guangzhou, Foshan, Dongguan, Zhongshan, and other cities. With the remarkable acceleration of spatial urbanization, a large amount of cultivated land, forest, and water areas became occupied by construction land.

Unused land showed the smallest change of area, with a decrease of $2.56 \mathrm{~km}^{2}$. Construction land and cultivated land were the main destinations of unused land.

\subsection{Overall Characteristics of the Eco-Environment Effects}

The regional eco-environmental quality index of the Pearl River Delta in 2000 and 2015 was calculated according to Formula (2). The results were 0.63 and 0.61 , respectively, indicating that the regional eco-environmental quality index of the Pearl River Delta urban agglomeration decreased over the study period, with an average annual decrease of $0.11 \%$. This shows that the ecological environmental quality of the Pearl River Delta region deteriorated between 2000 and 2015, which maintains the dynamic stability of the regional ecological environment overall.

The regional ecological quality tends to improve and deteriorate at the same time, while maintaining the overall stability of the regional ecological environment. These two trends offset each other in a certain region to a considerable extent, which leads to relative stability overall. The trend of ecological environmental improvement and deterioration can be drawn from the analysis of secondary land-use type change. Tables 5 and 6 show the area and contribution rates of the main land-use change types that led to the improvement and deterioration, respectively, of the ecological environment in the Pearl River Delta region over the study period.

Table 5. The major land-use transformation types that were improving the regional eco-environment.

\begin{tabular}{|c|c|c|c|c|c|}
\hline \multirow{17}{*}{ 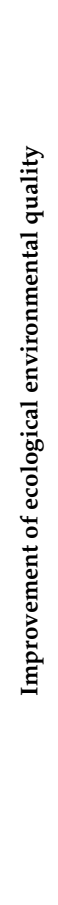 } & & $\begin{array}{l}\text { Conversion of } \\
\text { Land-Use Type }\end{array}$ & $\begin{array}{l}\text { Change Area } \\
\qquad\left(\mathrm{hm}^{2}\right)\end{array}$ & $\begin{array}{c}\text { Contribution } \\
\text { Rate }\end{array}$ & $\begin{array}{c}\text { Percentage of } \\
\text { Contribution } \\
(\%)\end{array}$ \\
\hline & \multirow{7}{*}{ 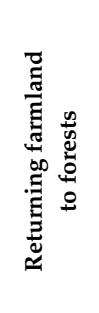 } & Paddy & 843.63 & 0.0001 & 1.48 \\
\hline & & Dryland-Forest & 3046.90 & 0.0004 & 5.75 \\
\hline & & $\begin{array}{l}\text { Dryland-other } \\
\text { forest land }\end{array}$ & 2473.39 & 0.0001 & 1.00 \\
\hline & & High-coverage & 2809.50 & 0.0001 & 1.52 \\
\hline & & Other & & & \\
\hline & & construction & 422.74 & 0.0001 & 0.91 \\
\hline & & Subtotal & 9596.16 & 0.0008 & 10.66 \\
\hline & \multirow{3}{*}{ 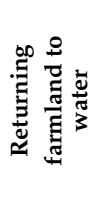 } & $\begin{array}{l}\text { Dryland- } \\
\text { Reservoir } \\
\text { pond }\end{array}$ & 4091.89 & 0.0002 & 3.31 \\
\hline & & $\begin{array}{l}\text { Other forest } \\
\text { land-Reservoir }\end{array}$ & 918.66 & 0.0001 & 0.87 \\
\hline & & Subtotal & 5010.55 & 0.0003 & 4.18 \\
\hline & \multirow{5}{*}{ 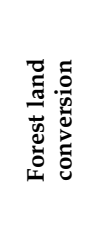 } & $\begin{array}{c}\text { Shrub } \\
\text { land-Forest }\end{array}$ & 1070.65 & 0.0001 & 0.87 \\
\hline & & Sparse & & & \\
\hline & & $\begin{array}{l}\text { woodland- } \\
\text { Forest }\end{array}$ & 4072.78 & 0.0004 & 5.49 \\
\hline & & $\begin{array}{l}\text { Other } \\
\text { forest-Forest }\end{array}$ & $41,001.09$ & 0.0042 & 60.80 \\
\hline & & Subtotal & $46,144.52$ & 0.0047 & 67.16 \\
\hline & & Total & $60,751.22$ & 0.0057 & 81.99 \\
\hline
\end{tabular}


Table 6. Major land-use transformation types causing deterioration of the regional eco-environment.

\begin{tabular}{|c|c|c|c|c|c|}
\hline \multirow{13}{*}{ 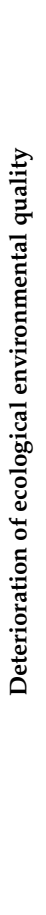 } & & $\begin{array}{l}\text { Conversion of } \\
\text { Land-Use Type }\end{array}$ & $\begin{array}{l}\text { Change Area } \\
\left(\mathrm{hm}^{2}\right)\end{array}$ & $\begin{array}{c}\text { Contribution } \\
\text { Rate }\end{array}$ & $\begin{array}{c}\text { Percentage of } \\
\text { Contribution } \\
(\%)\end{array}$ \\
\hline & \multirow{8}{*}{ 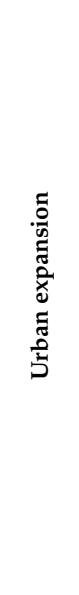 } & $\begin{array}{l}\text { Forest-Other } \\
\text { construction } \\
\text { land }\end{array}$ & 18458.40 & -0.003 & 13.25 \\
\hline & & $\begin{array}{l}\text { Forest-Urban } \\
\text { land }\end{array}$ & 17094.48 & -0.002 & 11.50 \\
\hline & & $\begin{array}{c}\text { Other forest } \\
\text { land-Urban land }\end{array}$ & 17402.84 & -0.001 & 3.12 \\
\hline & & $\begin{array}{c}\text { Paddy } \\
\text { field-Urban land } \\
\text { Paddy }\end{array}$ & $58,649.13$ & -0.001 & 5.26 \\
\hline & & $\begin{array}{l}\text { field-Other } \\
\text { construction } \\
\text { land }\end{array}$ & $37,714.09$ & -0.001 & 5.08 \\
\hline & & $\begin{array}{c}\text { Reservoir } \\
\text { pond-Rural } \\
\text { settlement }\end{array}$ & $10,326.77$ & -0.001 & 3.24 \\
\hline & & $\begin{array}{l}\text { Reservoir } \\
\text { pond-Other } \\
\text { construction } \\
\text { land }\end{array}$ & $16,231.56$ & -0.001 & 5.10 \\
\hline & & Subtotal & $175,877.27$ & -0.01 & 46.55 \\
\hline & \multirow{4}{*}{ ฮ્ } & $\begin{array}{l}\text { Forest-High } \\
\text { coverage } \\
\text { grassland }\end{array}$ & $13,534.70$ & -0.001 & 2.43 \\
\hline & & $\begin{array}{l}\text { Forest-Other } \\
\text { forest land }\end{array}$ & $67,589.16$ & -0.007 & 33.36 \\
\hline & & Subtotal & $81,123.86$ & -0.008 & 35.79 \\
\hline & & Total & $369,879.96$ & -0.021 & 82.35 \\
\hline
\end{tabular}

Table 5 showed that the types of land-use change that resulted in the improvement of the ecological environment quality in the Pearl River Delta region from 2000 to 2015 mainly included returning farmland to forest, returning farmland to water, and mutual transformation within forests. Among them, the ecological contribution rate of the internal conversion part of forest land was $67.16 \%$, mainly because other forest land was converted into forest land; the ecological contribution rate of returning farmland to forest was 10.66\%, mainly due to the conversion of dry land to forest land; the ecological contribution rate of returning farmland to water was $4.18 \%$, mainly due to the conversion of dry land into reservoir ponds.

Table 6 showed that the main driving factors leading to the deterioration of the ecological environmental quality in the Pearl River Delta region during 2000-2015 were the expansion of construction land and land degradation. The expansion of urban and rural construction land scale was mainly manifested in the transformation of cultivated land, forest, and water areas to urban and rural construction land. The conversion of landuse types into urban and rural construction land accounted for $46.55 \%$ of the ecological contribution rate, mainly due to the encroachment of construction land into the ecological space with forest land. The main manifestation of land degradation was the degradation of forest land into grassland or other forest land. The land degradation part accounted for $35.79 \%$ of the ecological contribution rate, mainly due to the encroachment of construction land into the ecological space with forest land. Overall, there were two trends of ecological improvement and deterioration in the Pearl River Delta region, but its overall habitat quality had maintained a stable trend

\subsection{Regional Characteristics of the Eco-Environment Effects}

According to Formula (2), it was found that land-use changes in the Pearl River Delta region between 2000 and 2015 led to various levels of change in the ecological environment quality of cities (Figures 4 and 5). Based on the spatial scale, Zhaoqing, Huizhou, and Jiangmen moderately had the higher eco-environment index values, which are scattered around the Pearl River Delta region. In contrast, Dongguan, Foshan, and Zhongshan which were concentrated in the central region of the Pearl River Delta, and they had the lowest eco-environment index. Guangzhou, as the capital of Guangdong province, had relatively 
good ecological quality, ranking fourth. Therefore, the ecological environment of the Pearl River Delta region was characterized by poor environmental quality of the central cities and good environmental quality of the surrounding cities. The eco-environmental index of cities in the Pearl River Delta region moderately decreased between 2000 and 2015. That of Dongguan, Shenzhen, and Zhongshan deteriorated considerably, with the ecoenvironmental index decreasing by $0.051,0.047$, and 0.046 , respectively. Huizhou, Zhuhai, and Jiangmen showed much less deterioration, with decreases to the eco-environment index of $0.007,0.007$, and 0.008 , respectively.

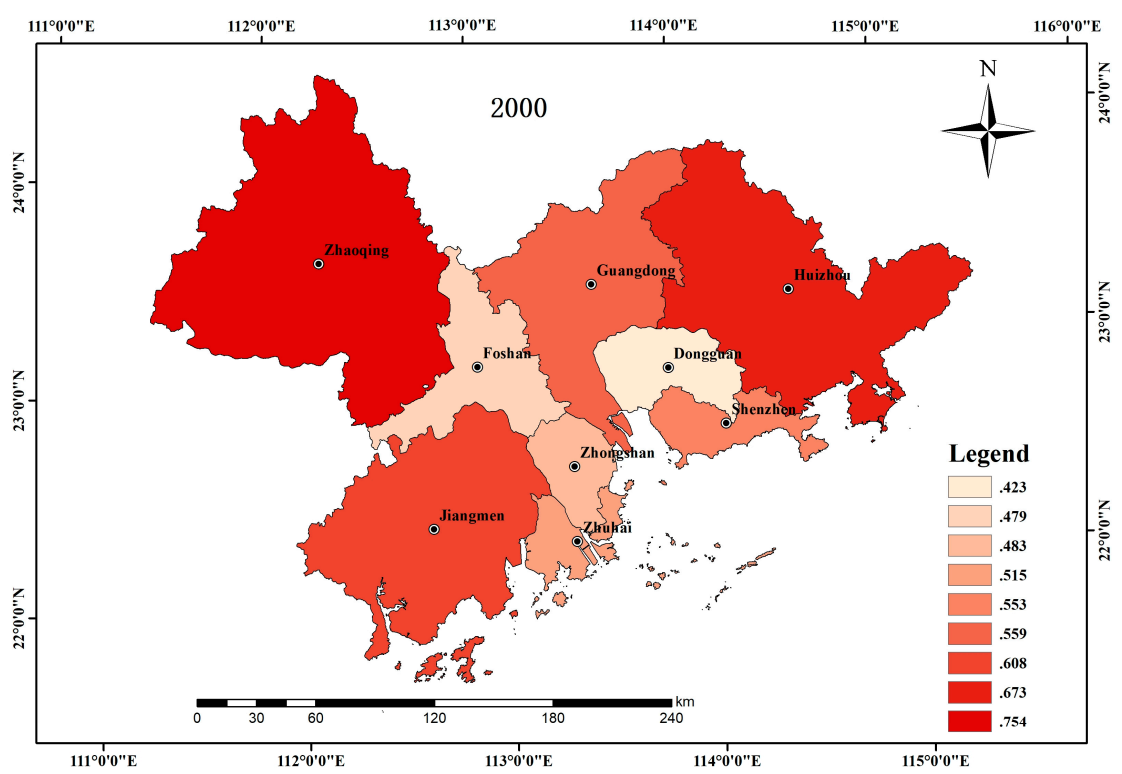

Figure 4. Distribution of eco-environmental quality in Pearl River Delta region in 2000.

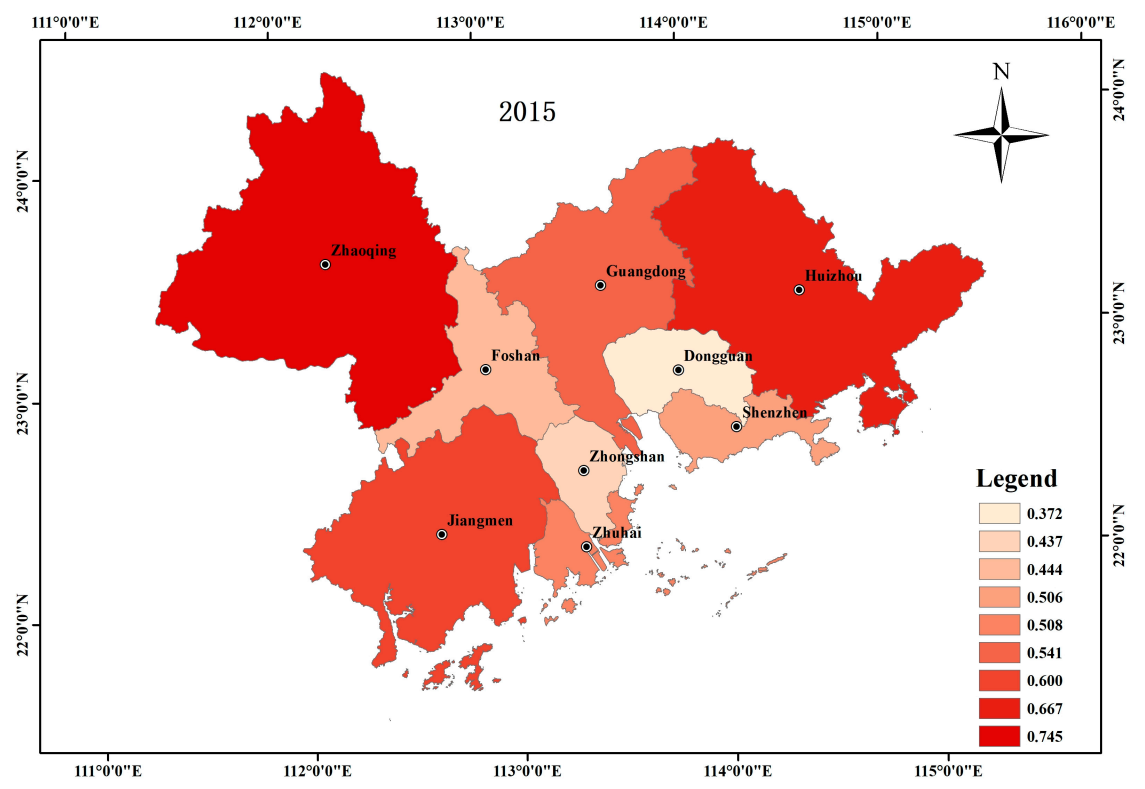

Figure 5. Distribution of eco-environmental quality in Pearl River Delta region in 2015.

These findings reveal that for cities such as Huizhou, with overall good ecological quality, there was a small ecological environment deterioration trend, whereas for cities such as Dongguan with relatively poor ecological quality, the deterioration trend was much greater. Therefore, the government should strengthen environmental protection 
supervision and balance the changing trend of the ecological environment quality for each city (Figure 6).

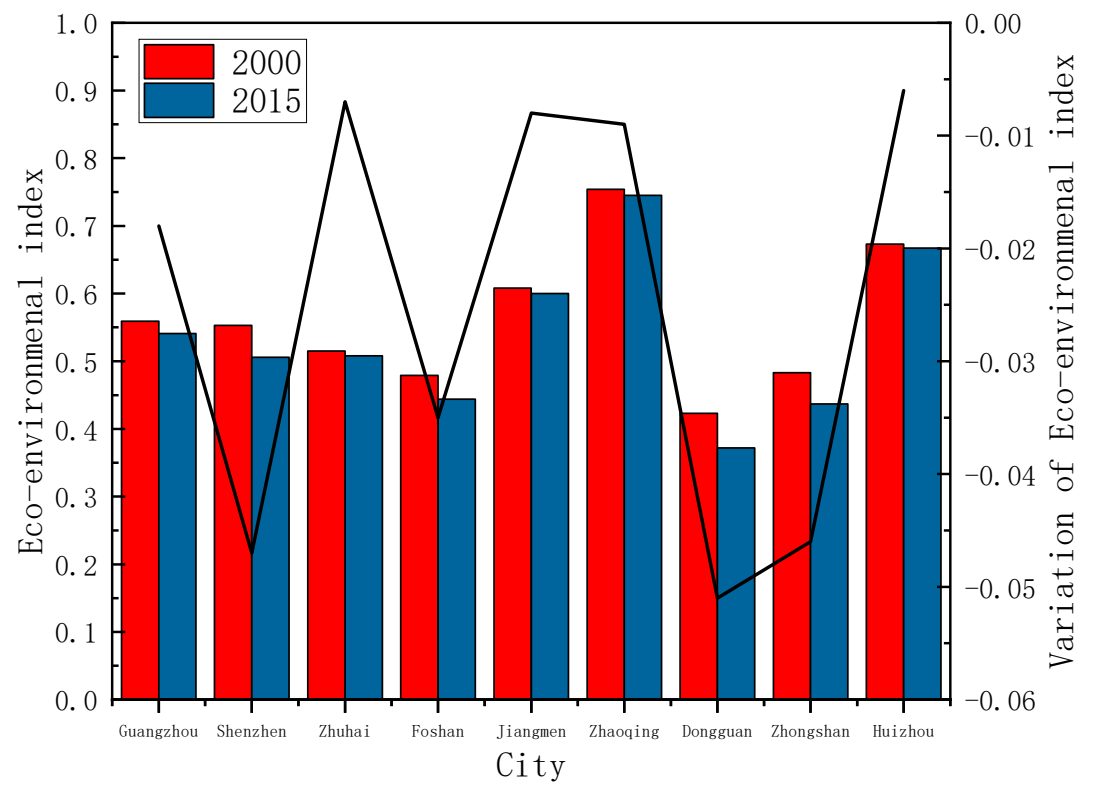

Figure 6. Eco-environmental quality index of cities in Pearl River Delta region from 2000 to 2015.

\subsection{Assessment of the Eco-Environmental Quality in the Pearl River Delta}

The eco-environment index of the Pearl River Delta region was clustered by using the Euclidean distance method in SPSS v.20 software (Table 7). According to the clustering results, nine administrative units in the study area were divided into five ecological quality grades (Figures 7 and 8 ).

Table 7. Standards for grading of eco-environmental quality in Pearl River Delta.

\begin{tabular}{cc}
\hline Eco-Environmental Quality Index & Grade Division \\
\hline$<0.3$ & Low-value zone \\
$0.3-0.45$ & Lower zone \\
$0.45-0.6$ & Moderate zone \\
$0.6-0.75$ & Higher zone \\
$>0.75$ & High-value zone \\
\hline
\end{tabular}

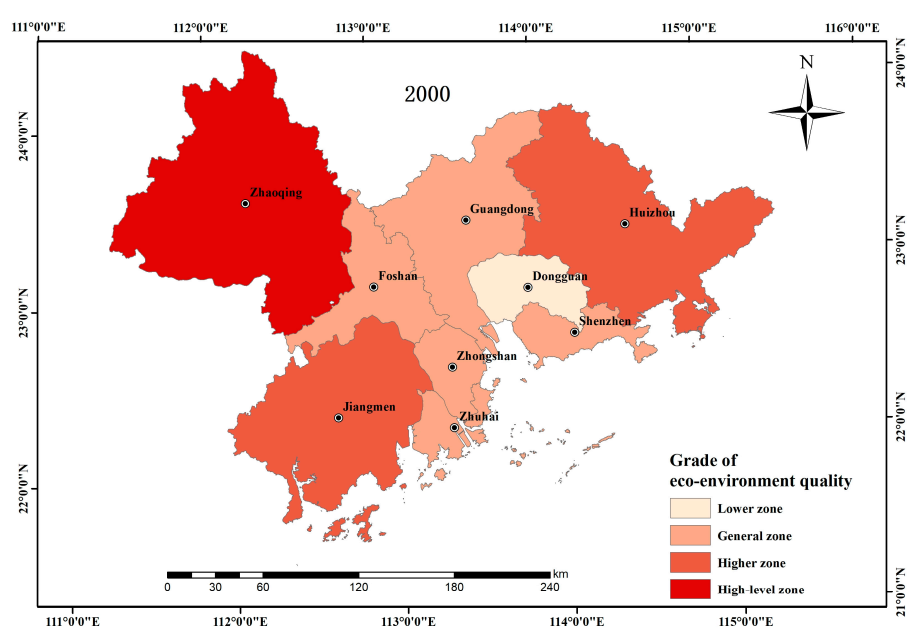

Figure 7. Distribution map of the grading of eco-environmental quality in Pearl River Delta region in 2000 . 


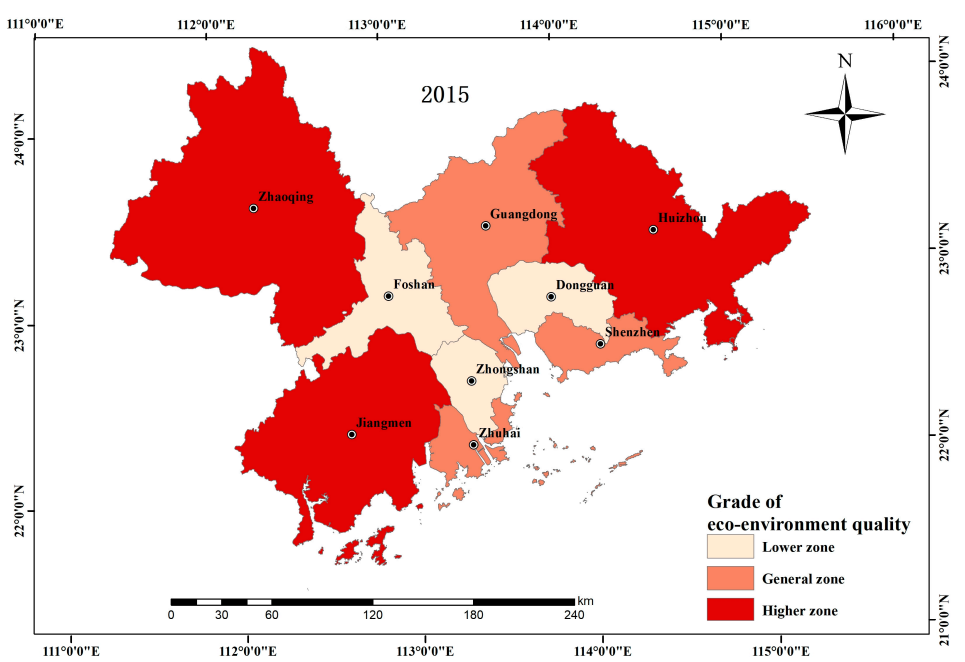

Figure 8. Distribution map of the grading of eco-environmental quality in Pearl River Delta region in 2015.

Overall, the ecological environment quality of all cities in the Pearl River Delta was higher than the low-value category; in 2000, the ecological environment quality was worst in Dongguan, and by 2015, the ecological quality of Foshan and Zhongshan had also been reduced from the moderate level to the same level as Dongguan, which is divided into lower levels. The quality of the ecological environment in most cities was at the moderate level and above. In 2000, the ecological index of Zhaoqing was higher than 0.75 , and the quality of ecological environment was classified as high level. A specific analysis of these findings is presented below:

(1) In the low-value zone of eco-environmental quality, the eco-environment index was lower than 0.30 . The ecological quality index of cities in the Pearl River Delta region consistently exceeded 0.3 , which shows that the overall level of the ecological environment quality in the Pearl River Delta is not the worst.

(2) In the lower zone of eco-environmental quality, the eco-environment index was between 0.3 and 0.45 . In 2000, only Dongguan belonged to the lower ecological quality area. In 2015, this category included Dongguan, Zhongshan, and Foshan. This comparison shows that the ecological environment quality of Zhongshan and Foshan cities reduced from the moderate level to the lower level. In the past 15 years, there has been rapid urbanization of Zhongshan and Foshan with areas of urban land increasing at the cost of land with a high ecological value such as forest and cultivated land.

(3) In the moderate zone of eco-environmental quality, the eco-environment index was between 0.45 and 0.60. In 2000, this category included Foshan, Zhongshan, Zhuhai, Shenzhen, and Guangzhou. In 2015, although the ecological environment quality of Shenzhen, Zhuhai, and Guangzhou declined, it remained within the moderate category. However, Foshan and Zhongshan declined from the moderate level to the lower level.

(4) In the higher zone of eco-environment quality, the eco-environment index was between 0.60 and 0.75 . In 2000, the ecological quality of Jiangmen and Huizhou was divided into this grade, whereas in 2015, Zhaoqing also joined this category. The comparative study showed that the eco-environment quality of Zhaoqing was the best among the nine cities. Only the eco-environment quality of Zhaoqing reached the higher level in 2000. The ecological environment quality of Jiangmen and Huizhou remained within the higher zone. Because of the good ecological environment of Jiangmen and Huizhou, a large number of land-use types with high ecological value, such as forest and grassland, are distributed in this area, and few natural disasters occur in these inland cities.

(5) In the high-value zone of eco-environment quality, the eco-environment index is higher than 0.75. In 2000, the overall ecological quality of Zhaoqing reached this level. This was because the land use in Zhaoqing was mainly based on land-use types with high 
ecological value, such as woodland, water, grassland, and so on, and the ecological effect was good. The city did not maintain this eco-environmental quality index level in 2015 and was transferred to the higher zone.

\section{Discussion}

Although the ecological environment of the Pearl River Delta maintained an overall balance during the period 2000-2015, it should not be ignored that the eco-environment index of each city decreased to varying degrees, with Dongguan, Shenzhen, and Zhongshan showing the greatest declines. The spatial differentiation of eco-environmental index was characterized by the high eco-environmental index of the surrounding and inland cities, such as Zhaoqing, Huizhou, and Jiangmen, whereas low eco-environmental index values were reported in the coastal cities of the central region, such as Dongguan, Foshan, and Zhongshan. These high and low eco-environmental index values were related to the difference in the regional ecological environment foundation. Therefore, efforts should be made to rebuild the ecological environment, limit, or avoid human activities that lead to negative development of the ecological environment, and make full use of the self-repairing function of the system.

From the research results, we can see that the urban expansion in the Pearl River Delta is prominent, and ecological spaces such as cultivated land, forest land, and wetland have been damaged to varying degrees. At the same time, part of the cultivated land has been turned into wetland, which shows that Guangdong Province has achieved remarkable results in implementing the policy of returning farmland to lakes. Therefore, relevant laws can be formulated to protect the corresponding ecological space of forest land. Regarding the protection of cultivated land, the management and control measures of the red line of cultivated land protection can be strictly observed. Regarding urban expansion, corresponding control policies can be formulated to limit the expansion of construction land, protect ecological space, and ensure regional ecological security.

In short, as one of the three major urban agglomerations in China, the Pearl River Delta has fulfilled the mission of ecological civilization development entrusted by the state and strived to build an "ecological plus" development strategy. However, this area is subject to a series of contradictions between man and land, such as the encroachment of cultivated land, forest, and water area; a sharp increase of population; and the decline of ecological environment quality. Firstly, we should make clear the basic ecological control line of the region, scientifically plan its ecological function structure, and invite environmental protection. Secondly, we should optimize the layout of regional industrial development, formulate the catalogues of industrial access for different groups, and guard against environmental risks from the source. Furthermore, we should fully implement the target responsibility system of energy conservation and emission reduction, adhere to intensive use of land resources, improve ecological carrying capacity, and leave room for the sustainable development of the Pearl River Delta urban agglomeration.

Although this paper studies the change trend and spatial pattern of land-use structure, it does not deeply explore the driving mechanism of land-use transformation in the Pearl River Delta region, which is a more concerned part in the study of land-use transformation. In the future, it is necessary to further study the driving mechanism of land-use transformation in various stages in combination with the economic and social development stages to further reveal the related problems of land-use transformation. At the same time, due to the lack of improvement on the existing ecological quality assessment methods, how to make the ecological environment quality index more in line with the objective reality, accurately determine the ecological environment quality index of different land-use types, and better evaluate the impact of different scales and different land-use classification systems on the assessment results needs to be further studied. 


\section{Conclusions}

According to the interpretation results of Landsat satellite remote sensing images, the quantitative indexes such as land-use coverage, comprehensive ecological environment quality index, and ecological contribution rate were used to realize the quantitative evaluation of the ecological environment effect of the Pearl River Delta region by revealing the correlation between land-use/land-cover and regional ecological environment quality.

(1) During 2000-2015, the land-use change in the Pearl River Delta mainly manifested in the reduction of cultivated land, forest, water areas, and unused land, and the increase of construction land and grassland. From the perspective of spatial distribution, it was concentrated in Guangzhou, Foshan, Dongguan, Zhongshan, and other cities. There was clear spatial urbanization in the Pearl River Delta region.

(2) From 2000 to 2015, the ecological environment of the Pearl River Delta largely maintained a relative balance but declined slightly overall. From 2000 to 2015, the comprehensive eco-environment index of the Pearl River Delta urban agglomeration decreased by 0.02 , among which forest, water areas, and cultivated land declined the most. The spatial expansion caused by urbanization had the most profound impact on the decline of regional ecological environmental quality.

(3) This modest overall decline masked more complex and extreme dynamics in the quality of ecological environment of individual city. Among them, Dongguan, Shenzhen, and Zhongshan are the cities with the largest decline. The spatial differentiation characteristics of the eco-environmental quality index indicate that the ecological quality preferences of cities distributed around the study area and close to the inland areas, while the ecological quality of the central coastal cities are biased. The quality of the ecological environment is related to the basis of the regional ecological environment. Decision analysis is required to support land-use planning to ensure the sustainability of ecosystem services for the wellbeing of the people of Pearl River Delta and other rapidly urbanizing areas in China and globally.

This study comprehensively evaluated the eco-environmental effects caused by the land-use change of the urbanization prominent region, revealed the problems existing in the process of land development and ecological construction in the Pearl River Delta urban agglomeration region, and provided policy suggestions for the coordinated development of urbanization and ecological environment in the region. At the same time, it also provided a reference for the research on the eco-environmental effects of land-use change in key cities in economically developed areas.

Author Contributions: Conceptualization, P.H. and D.H.; methodology, F.L.; software, P.H. and X.C.; validation, P.H., X.S. and Y.L.; formal analysis, Y.L.; investigation, P.H. and X.C.; resources, X.S.; data curation, P.H. and X.S.; writing-original draft preparation, P.H.; writing—review and editing, F.L., D.H. and X.S.; visualization, P.H.; supervision, D.H.; project administration, F.L.; funding acquisition, F.L. All authors have read and agreed to the published version of the manuscript.

Funding: This research was funded by the National Key Research and Development Plan under Grant No. 2016YFC0502800 and National Natural Science Foundation of China under Grant No. 71734006 and 71533004.

Institutional Review Board Statement: I choose to exclude this statement because the study did not involve humans or animals.

Informed Consent Statement: I choose to exclude this statement because the study did not involve humans.

Data Availability Statement: This study is based on the land-use data produced by the Institute of Geographic Sciences and Natural Resources Research, Chinese Academy of Sciences.

Conflicts of Interest: The authors declare no conflict of interest. 


\section{References}

1. Yang, Y.; Cai, Z. Ecological security assessment of the Guanzhong Plain urban agglomeration based on an adapted ecological footprint model. J. Clean. Prod. 2020, 260, 120973. [CrossRef]

2. Shi, R. Ecological Environment Problems of the Three Gorges Reservoir Area and countermeasures. Procedia Environ. Sci. 2011, 10, 1431-1434. [CrossRef]

3. Haryadi, D.; Ibrahim, I.; Darwance, D. Strategic Ecological Issues: Environmental Problems in a Perspective of Regional Development in Bangka Belitung. In E3S Web of Conferences, Proceedings of the 2020 8th International Conference on Environment Pollution and Prevention (ICEPP 2020), Sydney, Australia, 3-5 December 2020; EDP Sciences: Les Ulis, France, 2021; Volume 241, p. 05001.

4. Liu, M. An Empirical Study on the Relationship between Urbanization and Ecological Environment Quality. Technol. Dev. Enterp. 2016, 35, 1-5.

5. Xiong, Y.; Xu, W.; Lu, N.; Huang, S.; Kou, W. Assessment of spatial-temporal changes of ecological environment quality based on RSEI and GEE: A case study in Erhai Lake Basin, Yunnan province, China. Ecol. Indic. 2021, 125, 107518. [CrossRef]

6. Zhang, Y.; Long, H.; Tu, S.; Ge, D.; Ma, L.; Wang, L. Spatial identification of land use functions and their tradeoffs/synergies in China: Implications for sustainable land management. Ecol. Indic. 2019, 107, 105550. [CrossRef]

7. Kulczyk-Dynowska, A.; Bal-Domańska, B. The National Parks in the Context of Tourist Function Development in Territorially Linked Municipalities in Poland. Sustainability 2019, 11, 1996. [CrossRef]

8. Siche, J.R.; Agostinho, F.; Ortega, E.; Romeirocet, A. Sustainability of nations by indices: Comparative study between environmental sustainability index, ecological footprint and the emergy performance indices. Ecol. Econ. 2008, 66, 628-637. [CrossRef]

9. Li, J.; Jiang, C.; Xing, Z. Multi-dimensional influence measurement of urbanization on the quality of natural living environment in China. Environ. Dev. Sustain. 2021, 17, 1-18.

10. Li, X.; Fang, C.; Huang, J.; Mao, H. The urban land use transformations and associated effects on eco-environment in northwest china arid region: A case study in Hexi region, Gansu province. Quat. Sci. 2003, 23, 280-290.

11. Deng, W.; Yang, H.; Cui, Y.J. Assessment of Ecological Environmental Effects on Landuse Change in Chongqing City Nearly 30 Years. Res. Soil Water Conserv. 2010, 17, 232-236.

12. Yang, S.; Yan, H.; Guo, L. The Land Use Change and Its Eco-environmental Effects in Transitional Agro-pastoral Region-A Case Study of Yulin City in Northern Shaanxi Province. Prog. Geogr. 2004, 23, 49-55.

13. Lv, L.; Zhou, S.; Zhou, B.; Dai, L.; Chang, T.; Bao, G.; Zhou, H.; Zhi, L. Land Use Transformation and Its Eco-environmental Response in Process of the Regional Development: A Case Study of Jiangsu Province. Sci. Geogr. Sin. 2013, 33, 1442-1449.

14. Wuletawu, A.; Lulseged, T.; Assefa, A.; Habtamu, H.; Kristin, P.; Mats, S.; Evan, G.; Rolf, S. Estimating spatially distributed SOC sequestration potentials of sustainable land management practices in Ethiopia. J. Environ. Manag. 2021, $286,112191$.

15. Yang, Y.; Wang, L.; Yang, F.; Hu, N.; Liang, L. Evaluation of the coordination between eco-environment and socioeconomy under the "Ecological County Strategy" in western China: A case study of Meixian. Ecol. Indic. 2021, 125, 107585. [CrossRef]

16. Zhou, X. Spatial explicit management for the water sustainability of coupled human and natural systems. Environ. Pollut. 2019, 251, 292-301. [CrossRef]

17. Cai, J.; Li, X.; Liu, L.; Chen, Y.; Lu, S. Coupling and coordinated development of new urbanization and agro-ecological environment in China. Sci. Total Environ. 2021, 776, 145837. [CrossRef]

18. Miyamoto, A.; Sano, M.; Terazono, R.; Yamada, S.; Shimizu, A. Assessment of wood provisioning in protected subtropical forest areas for sustainable management beyond the zone. J. Environ. Manag. 2021, 287, 112337. [CrossRef]

19. Yang, Q.; Gao, H.; Zhanbin, L.I.; Wang, J. Effects of Land Use Change in Watershed on Base flow in Arid Area. Res. Soil Water Conse. 2018, 25, 317-322.

20. Yang, Q.; Duan, X.; Wang, L.; Jin, Z. Land Use Transformation Based on Ecological-production-living Spaces and Associated Eco-environment Effects: A Case Study in the Yangtze River Delta. Sci. Geogr. Sin. 2018, 38, 97-106.

21. Wu, J.; Feng, Z.; Gao, Y.; Peng, J. Research on ecological effects of urban land policy based on DLS model: A case study on Shenzhen City. Acta Geogr. Sin. 2014, 69, 1673-1682.

22. Yang, J.; Wu, T.; Pan, X.; Du, H.; Li, J.; Zhang, L.; Men, M.; Chen, Y. Ecological quality assessment of Xiongan New Area based on remote sensing ecological index. China J. Appl. Ecol. 2019, 30, 277-284.

23. Zhang, Z.; Gao, J.; Gao, Y. The influences of land use changes on the value of ecosystem services in Chaohu Lake Basin, China. Environ. Earth Sci. 2015, 74, 385-395. [CrossRef]

24. Zhao, C.; Xiaohua, G.U.; Jiang, H.; Zeng, L.I.; Zhu, Y.; Lian, Z. Study on Eco-environmental Effects of Land Use Change of Three River Basin in Yunnan Province. Res. Soil Water Conse. 2016, 23, 240-243.

25. Yu, Z.; Zhang, P.; Feng, T.; Li, Z.; Xu, Z. The effects of land use changeon habitat quality in Changli county based on invest model. China J. Agric. Resour. Reg. Plan. 2018, 39, 121-128.

26. Wan, W.; Wei, W.; Qian, D.; Wei, X.; Feng, K. Progress on the environmental effects of land use and land cover change. J. Fujian Agr. For. Univ. 2017, 46, 361-372.

27. Du, X.; Lv, C.; Wang, H. Review: Researches on Environmental Effects of Land Use/Cover Change. Soils 2011, 43, 350-360.

28. Liu, B.; Bian, Y.; Zhou, M.; Zhu, J. 70 Years Review of China's Regional Economic Development and Its Prospect. China Ind. Econ. $2019,9,24-41$. 
29. Zhang, L.; Wang, Z. Guangdong-Hong Kong-Macao Greater Bay Area: Evolution, Reference and Strategic Suggestion. Reform. Strateg. 2018, 34, 73-77.

30. Liu, J.Y.; Zhang, Z.X.; Xu, X.L.; Kuang, W.H.; Zhou, W.C.; Zhang, S.W.; Li, R.D.; Yan, C.Z.; Yu, D.S.; Wu, S.X. Spatial patterns and driving forces of land use change in China during the early 21st century. J. Geogr. Sci. 2010, 20, 483-494. [CrossRef]

31. Wang, X.; Bao, Y. Study on the methods of land use dynamic change research. Prog. Geogr. 1999, 18, 81-87.

32. Ying, W.; Li, X.; Li, J. Study on the response of ecological capacity to land-use/cover change in Wuhan city: A remote sensing and GIS based approach. Sci. World J. 2014, 2014, 794323.

33. Liu, Y.; Gao, J.; Yang, Y. A Holistic Approach towards Assessment of Severity of Land Degradation along the Great Wall in Northern Shaanxi Province, China. Environ. Monit. Assess. 2003, 82, 187-202. [CrossRef] [PubMed] 